Radical positivism is far more concerned with practice and experiment than with knowledge, and is equivalent to a calculus whereby future events in the realm of the inorganic can be predicted, and whereby knowledge-as admitted by the Vienna circle-is identified with control of Nature. But in Dr. May's opinion, knowledge is more than the logical framework of a mathematics of matter, and philosophy must not degenerate into an 'ancilla mathematicorum'.

Dr. Vogel, of Bad Nauheim, who approaches the subject from the point of view of language and philosophy, considers that every advance in knowledge necessarily changes the concept of knowledge. Hence the difficulty in determining epistemologically the nature of objective reality. The concept 'reality' does not belong to science at all-it lies beyond, limits science from outside and changes as the frontiers of science extend. But Dr. Vogel thinks that in its basic structure the nature of reality will always be determined by direct experience of the surrounding world (without its ever being possible to determine exactly in what this fundamental structure consists). The thing to remember and reject is the belief-held by most practising physicists-that abstract calculi constitute the whole of science; especially as the most essential feature, namely, the relationship between abstract quantities and experimental science, can never be expressed in a calculus at all. Quantum mechanics is responsible for the discovery that conditions exist which must be altered by man before he can observe them. So that all we can say is that absolute knowledge does not appear to exist. To which we might perhaps add the qualifying reflection that it may some day become possible to include this fact itself in an extended and more adequate theory of knowledge.

\section{Amethe von ZepPeLin.}

\title{
Essays in Heredity
}

\section{(I) The Study of Heredity}

By E. B. Ford. (The Home University Library of Modern Knowledge.) Pp. 256. (London: Thornton Butterworth, Ltd., 1938.) $2 s .6 d$. net.

\section{(2) The Measurement of Linkage in Heredity}

By Dr. K. Mather. (Methuen's Monographs on Biological Subjects.) Pp. ix +132 . (London : Methuen and Co., Ltd., 1938.) 4s. $6 d$. net.

THESE two competently designed books illustrate, in their different ways, the wide field covered by genetics. They will go far to counteract the erroneous impression now prevalent that genetios is primarily composed of cytological and mathematical complexities. The books obviously reflect the fact that they are written by well-known practising geneticists.

(1) "The Study of Heredity" is designed to give an outline of modern thought on variation, selection, sex, mimicry, human genetics, the species concept and other subjects concerning which many exaggerated views exist in popular imagina. tion. By describing the way in which genetical knowledge has evolved and by developing the main theme of the gene concept, Mr. Ford has effectively put such subjects as evolution, sex, and origin of variation in their proper place. For those who have not had the "advantage of dissecting pregnant mice" (p. 243) the essay, well documented with facts, will provide an excellent introduction to the recent knowledge of heredity. It is unfortunate that the author repeats the fallacious story of the influence of temperature on red-flowered Primula sinensis; the red-flowered variety does not turn white at high temperatures as is generally supposed.

(2) Dr. Mather's book fills a long-felt want of practising geneticists who feel insecure in using statistical methods. While the statistical material is fully dealt with, the nature of biological experiments is always fully realized. Quite frequently it is necessary to discover the significance of segregation ratios, to measure linkage and to combine the results from different families. Dr. Mather supplies suitable statistical methods, well illustrated by examples, which, exceptionally for a statistical book, are fully worked out. Novel methods, resulting from the properties of the $\chi^{2}$ function, are provided for the measurement of heterogeneity, and to meet the difficulties due to disturbed segregation ratios. Finally, a chapter is devoted to statistical methods for the genetical analysis of the refractory material of man. The tables provided enable one to carry out all the more usual computations for genetical experimentation. The non-mathematical reader should be able to extract much help from this clearly written book, which begins with elementary facts, and carries the reader to an advanced stage in statistical methods for genetical work.

F. W. SANSOME. 